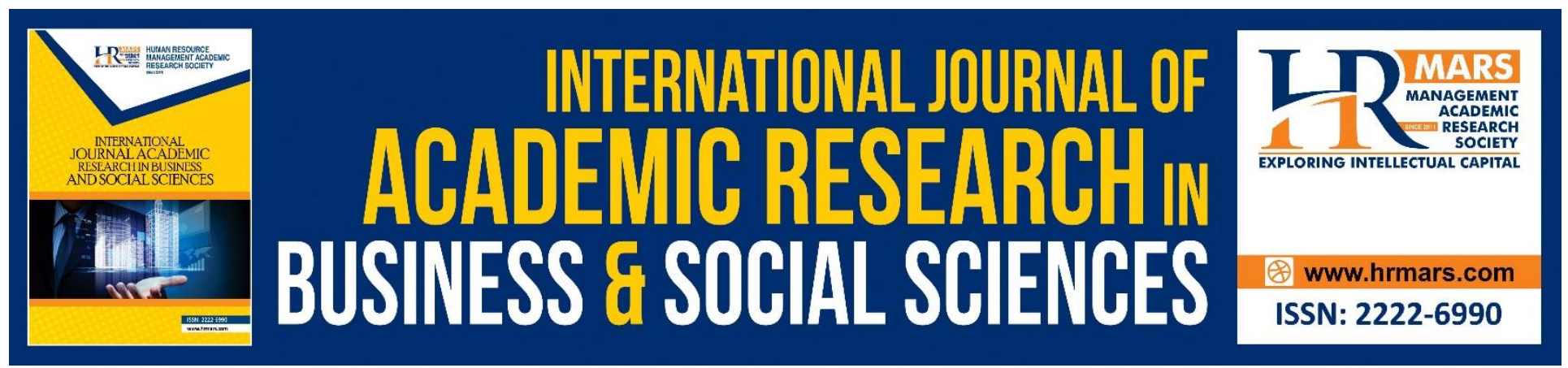

\title{
Adaptive Behavior towards Work Environment among Internship Students
}

\begin{abstract}
Noraznira Abd Razak, Najihah Hanisah Marmaya, Rizuwan Abu Karim, Nur Melissa Bte Mohammad Faisal Wee, Abdul Rauf Bin Ridzuan
\end{abstract}

To Link this Article: http://dx.doi.org/10.6007/IJARBSS/v8-i11/4889

DOI: $10.6007 /$ IJARBSS/v8-i11/4889

Received: 04 Sept 2018, Revised: 11 Oct 2018, Accepted: 21 Oct 2018

Published Online: 23 Nov 2018

In-Text Citation: (Razak, Marmaya, Karim, Wee, \& Ridzuan, 2018)

To Cite this Article: Razak, N. A., Marmaya, N. H., Karim, R. A., Wee, N. M. B. M. F., \& Ridzuan, A. R. Bin. (2018). Adaptive Behavior towards Work Environment among Internship Students. International Journal of Academic Research in Business and Social Sciences, 8(11), 130-137.

Copyright: (C) 2018 The Author(s)

Published by Human Resource Management Academic Research Society (www.hrmars.com)

This article is published under the Creative Commons Attribution (CC BY 4.0) license. Anyone may reproduce, distribute, translate and create derivative works of this article (for both commercial and non-commercial purposes), subject to full attribution to the original publication and authors. The full terms of this license may be seen at: http://creativecommons.org/licences/by/4.0/legalcode

Vol. 8, No. 11, 2018, Pg. 130 - 137

http://hrmars.com/index.php/pages/detail/IJARBSS

JOURNAL HOMEPAGE

Full Terms \& Conditions of access and use can be found at http://hrmars.com/index.php/pages/detail/publication-ethics 


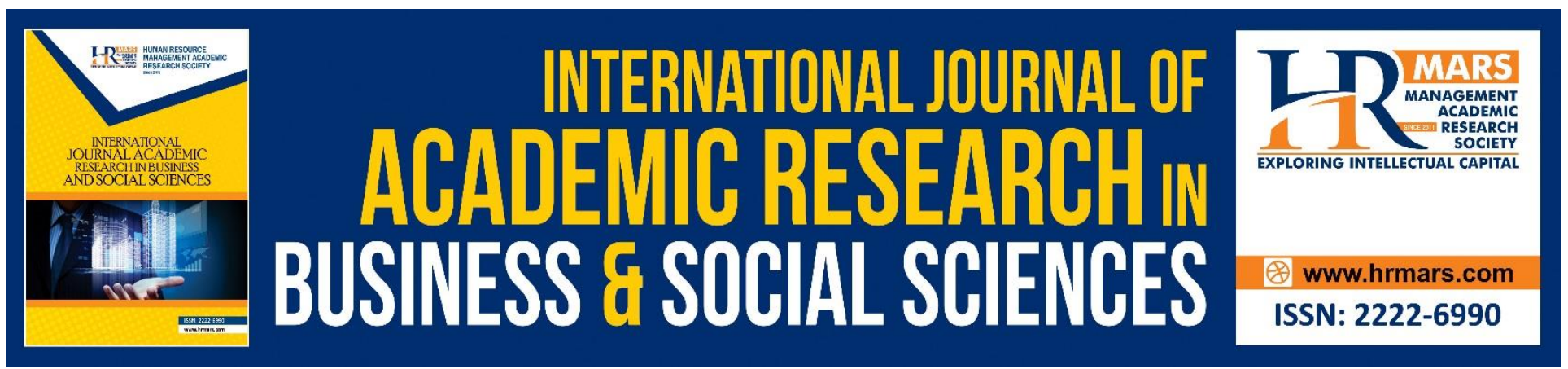

\title{
Adaptive Behavior towards Work Environment among Internship Students
}

\author{
Noraznira Abd Razak, Najihah Hanisah Marmaya, Rizuwan Abu \\ Karim, Nur Melissa Bte Mohammad Faisal Wee, Abdul Rauf Bin \\ Ridzuan \\ Universiti Teknologi MARA Melaka, Malaysia
}

\begin{abstract}
The study is conducted to identify the adaptive behaviours towards working environment among internship students in UiTM Malacca City Campus and the relationship between perceived severity, perceived vulnerability, perceived response efficacy and perceived self-efficacy with adaptive behaviours in a working environment. This study involved 55 internship students in UiTM Malacca City Campus who answered the questionnaires that had been distributed. This study adopted Protection Motivation Theory (PMT) as main underlying framework to further explained the variables involved.
\end{abstract}

Keywords: Behavior, Work environment, Perceived Severity, Perceived Vulnerability.

\section{Introduction}

Griffin and Hesketh (2003) stated that the work environment requires certain tasks to be performed, while the individual brings capabilities such skills and abilities to bear on these tasks. It stated that a good fit between work environment's requirement and the employee's skills results in satisfactory performances. Adapting to a working environment can sometimes be hard for fresh graduates and those that are just entering into the internship phase of their studies. After studying for more than a decade, people can have difficulties adjusting to a new set of different environment. A mismatch between an environment and the people working in it comes as an effect of changes(Griffin and Hesketh, 2003). One of the challenge is that they need to work out how to get along with a wide range of people on a daily basis (Black, 2013). Employees that have found that their knowledge, skills, abilities (KSA) and needs no longer fit with the new requirements, would resort to adaptation for the first time(Niessen, Swarowsky, \& Leiz, 2010).

Employees need to possess a willingness to respond to and support change in addition to high capabilities or competencies, in order to respond effectively to changing job requirements and organizational environment(Wu, Tian, Luksyte, and Spitzmueller, 2016). Fresh graduates need to be 
aware of the fact that they will also be working with a much wider range of people that comes from a range of demographic, age, education and social backgrounds and they should be able to work effectively with them(Black, 2013). In order to predict adaptive performance of an individual, a measure of behavioral adaptability which is based on the large body of work which argues that past performance is the best predictor of successful future performance, is used(Griffin \& Hesketh, 2003). A study conducted by Leadership IQ in the United State shows that only $19 \%$ newly-hired employees achieved complete success, while a staggering $46 \%$ are looking into abject failure within 18 months, facing negative performance review, disciplinary action or termination. Furthermore, it has been found that these newly-hired employees are failing, not because of their technical skills but rather because of their poor interpersonal skills (Murphy, 2015).

\section{Literature Review}

Protection Motivation Theory (PMT) is a major health psychology theory aimed at explaining the cognitive mediation process of behavioural change in terms of threat and coping appraisal. The PMT's threat appraisal component (Plotnikoff \& Trinh, 2010) is composed of the following: the person's estimate of the severity of the threat (perceived severity) and his or her estimate of the chance or probability of the occurrence of the threat (perceived vulnerability). The PMT further stipulates that the emotional state of fear arousal influences attitudes and behaviour change indirectly through the appraisal of the severity of the danger. The model's coping appraisal consists of the individual's expectancy that carrying out recommendations can remove the threat (response efficacy) and belief in one's capability to execute the recommended course of action successfully (self-efficacy). (Plotnikoff \& Trinh, 2010).

\section{- Perceived Severity}

Perceived severity show how the individual believes seriousness the threat would impact be to his or her own life (Milne \& Lnrted, 2000). Behaviour will change based on not only the level of fear induced by the event but also as a function of a person's actual ability to cope and the social norms and values within the job environment. Fear is seen as an intervening variable; the more vulnerable an individual feels to a threat and the more serious he or she believes it to be, the more fear will be aroused and the greater the appraised threat will be. The greater the perceived threat, the individual more to be motivated to protect their selves and eventually lead to behavioural intention to adopt a protective behaviour will be formed. This is measured by item such as adaptive behaviour is important in the job environment(Milne \& Lnrted, 2000). Thus, perceived severity is considered such how individual manage the fear in adaptive behaviour towards working environment. In this research, the impact of the perceived severity will describe the ways of students in adaptive behaviours on working environment.

\section{- Perceived Vulnerability}

Perceived vulnerability assesses how personally susceptible an individual feels to the communicated threat. It is not something that can be typically measured, but it can usually be measured by items such as "Considering all of the different factors that may contribute to job environment, including your own past and present behaviour, what would you say are your chances of successfully adapting 
with the new job environment?"(Milne \& Lnrted, 2000). One study that has been conducted shows that a participant that is feeling a state of vulnerability, would processed information systematically, except when peripheral processing is enough to find reassurance(Gleicher, 1990). On the other hand, another study found that feeling vulnerable would increase the elaboration of information that is found to be relevant and any irrelevant information would not be elaborated successfully(Meljnders 2 et al., 2001).

\section{- Perceived Self Efficacy}

Griffin and Hesketh (2003) found evidence that adaptive self-efficacy is positively related to adaptive performance. Self-efficacy is defined as people's judgement of their capabilities to organize and execute the courses of action required to attend designated types of performances. It influences on human functioning through motivational, cognitive and affective processes and shape developmental trajectories by influencing the choice of pursuits and selection of environments. People with higher levels of self-efficacy will set higher goals or themselves and be more persistent in attaining these goals, which results in better performance. Self-efficacy, which closely related to one's belief about one ability to cope with work environment. Self-efficacy perceptions could also influence the choice of an adaptive strategy, when in a certain problem situation, several coping alternatives are available. For instance, if the student considered learning in adaptive behaviour towards working environment as the optimal solution and within his capabilities (his self-efficacy) he would be more likely to choose this option than in the instance where he would consider it as exceeding his capabilities.

\section{- Perceived Response Efficacy}

Response efficacy is a central concept in several adaptive behaviour in working environment and Protection Motivation Theory (Rogers, 1975, 1983). As is the case with self-efficacy, response efficacy sometimes is conceptualized as a feature of a message, such as when a message has responseefficacy characteristics (e.g., Lapinski, 2006; Rimal \& Real, 2003) and it is often conceptualized reliance in the ability of a recommended behaviour to adaptive behaviour in working environment.Response efficacy is the confidence that adaptive response will work, that taking the protective action will be practical in protecting their self or others. Response efficacy and self-efficacy will increase the probability of selecting the adaptive response.

Coping appraisal involves the individual's assessment of the effectiveness of the proposed adaptive behaviour to avoid the danger, as well as the perceived ability to carry out the recommended actions. Within Protection Motivation Theory (PMT), response efficacy is a part of a second appraisal (coping) comply with exposure to a dread appeal message. If a perceived threat (threat appraisal) is judged to be high, then an individual will capture in evaluate both self and response efficacy. If both efficacy appraisals are judged to be sufficiently high, then an individual will be more motivated to lower the threat (by adopting message recommendations). If one or both of the efficacy appraisals are insufficiently, then the individual will be motivated to lower fright by a number of different strategies. 


\section{- Adaptive Behaviour Towards Work Environment}

Individual adaptive behavior or "the level to which individuals cope with, respond to, and or support changes that affect their roles as individuals has been considered crucial work behavior for both individuals and organizations. (Wu et al., 2016). Individuals have to adapt to the direct consequences of change to be effective when work requirements change. Adaptation to change in the workplace goes beyond merely learning new knowledge and skills. It also requires the unlearning of old work procedures, the accomplishment of tasks and duties in light of the change (Niessen et al., 2010). Besides, workplace undertakes major changes in the organization and technology with significant effects on the employees. Thus, organizations have expectation where employees can adapt quickly without any problem due to changes in the workplaces. Employees are considered adaptive when they can perform well during change. (Niessen et al., 2010).

Thus, four hypotheses has been established for this research namely :

H1: There is a significant relationship between perceived severity and adaptive behaviour towards job environment.

H2: There is a significant relationship between perceived vulnerability and adaptive behaviour towards job environment.

H3: There is a significant relationship between perceived response efficacy and adaptive behaviour towards job environment.

H4: There is a significant relationship between perceived self-efficacy and adaptive behaviour towards job environment.

\section{Research Methodology}

Under the theoretical model, perceived severity on this research is focused on the students' action of protective of himself. Next is perceived vulnerability as it focused on the companies' action on viewing the students' competencies. Other than that is perceived self-efficacy that enhances students' opinion on their job environment. Lastly is perceived response efficacy which focused on the students' feedback on their job environment. The sample respondent of this research is 55 internship students in UiTM Malacca City Campus. The scope of the study is the respondents from the population of the internship students that are now having their internship on their final semester. The survey is conducted via distribution of questionnaire. There are 55 questionnaires has been distributed to the respondents and it is completely answered and obtained. Researcher used SPSS Software version 20.0, "Statistical Process for Social Science" to acquire the analysis.

\section{Results and Discussion}

- Demographic Summary

The summary of demographic analysis of the respondents shows the frequency and percentage of respondents based on gender, age, courses, race, and marital status. Based on the result shown, there are 17 of male respondents and 38 of female respondents out of 55 respondents. Therefore, male respondents represented $30.9 \%$ of total respondents while female $69.1 \%$ represented female respondents. The descriptive analysis show majority of respondents are at age of 23 with 18 respondents. Therefore, this age represent $32.7 \%$ of total respondents followed by age of 22 with 16 respondents. They present $29.1 \%$ of total respondents. Then, with age of 24 which presented $14.5 \%$ 
of total respondents. Meanwhile, total number age of 21 and 26 and above is 6 and 4 respondents. It is represent $10.9 \%$ and $7.3 \%$ of total number respondents respectively. Age of 25 consist only 3 respondents and $5.5 \%$ of total number of respondents.

The majority of the respondents comprise of Malay race with 53 respondents out of 55 respondents which presented $96.4 \%$ of total respondents. Meanwhile, for Iban and Melanau, they shared the same number of respondents which is 1 respondent each. Therefore, both of them represented $1.8 \%$ each of total respondents which then make them the least respondents of the study. The higher percentage of respondent of this study comes from human resources program which consists of 23 numbers of respondents and cater for $41.8 \%$ of total respondents. Followed by marketing and international business program consists of 13 and 9 total numbers of respondents. The percentage is $23.6 \%$ and $16.4 \%$ respectively. The office system program which is 5 respondents and $9.1 \%$ of total respondents. Meanwhile, respondents from finance program are 3 respondents and the percentage is 5.5. The least number of respondents are from hotel and tourism management program that only comprised of 2 respondents and $3.6 \%$ of total respondents.

\section{- Multiple Regression Analysis}

Cronbach Alpha value for this study is 0.715 which is indicates that coefficient reliability is good. $\mathrm{R}^{2}$ for this study shows $21.3 \%$ of variance of adaptive behaviour towards work environment. The percentage of variance in the independent variable that explained by the variation in the independent variables. While the rest of the $78.7 \%$ of the variance in independent variables show the result could not be explained in this study. Hence, there were other independent variables which are not included in this study that can explain the regression equation. Multiple Regression Analysis has been used to test the hypotheses established for this study. Table 1 shows the finding of the analysis.

\section{TABLE 1}

\begin{tabular}{|c|c|}
\hline Hypothesis & Findings \\
\hline $\begin{array}{l}\text { H1 There is a negative relationship between perceived } \\
\text { severity and adaptive behaviour towards job } \\
\text { environment }\end{array}$ & Not Supported \\
\hline $\begin{array}{l}\text { H2 There is a negative relationship between perceived } \\
\text { vulnerability and adaptive behaviour towards job } \\
\text { environment }\end{array}$ & Not Supported \\
\hline $\begin{array}{l}\text { H3 There is a negative relationship between perceived } \\
\text { self-efficacy and adaptive behaviour towards job } \\
\text { environment }\end{array}$ & Not supported \\
\hline $\begin{array}{l}\text { H4 There is a positive relationship between perceived } \\
\text { response efficacy and adaptive behaviour towards job } \\
\text { environment }\end{array}$ & Supported \\
\hline
\end{tabular}

Table 1: HYPOTHESES RESULT

The result shows that perceived severity did not have a significant relationship with adaptive behaviour towards job environment as the $p$-value is higher than $0.05 \quad(p=0.359)$. Perceived vulnerability and perceived self efficacy also did not have a significant relationship with adaptive behaviour towards work environment as the $p$-value is higher than $0.05(p=0.286)$ and $(p=0.993)$ respectively. Therefore, hypothesis 2 and 3 also not supported and cannot be accepted. On the other 
INTERNATIONAL JOURNAL OF ACADEMIC RESEARCH IN BUSINESS AND SOCIAL SCIENCES

Vol. 8, No. 11, Nov, 2018, E-ISSN: 2222-6990 @ 2018 HRMARS

hand, the result shows that perceived response efficacy have a significant relationship with adaptive behaviour towards job environment as the $p$-value is lower than $0.05 \quad(p=0.019)$. Therefore, hypothesis 4 is supported.

\section{Conclusion}

This study found that the significant relationship between perceived response efficacy and adapting behavior towards working environment may be because when people improve their self-esteem, they will become more motivated and it influence adaptive behaviour in working environment (Hensel, Leshner, \& Logan, n.d.). This is already posited by PMT theory which stated that the response efficacy is theoretically linked to people's beliefs about their own rewards and not those that might occur for others.

\section{References}

Benn, S., Teo, S. T. T., \& Martin, A. (2015). Employee participation and engagement in working for the environment. Personnel Review, 44(4), 492-510. https://doi.org/10.1108/PR-10-2013-0179

Black, J. (2013). From student to young professional: what to expect from working life.

Gleicher, F. and R. E. P. (1990). Expectations of Reassurance Influence the Nature of FearStimulated Attitude Change. Experimental Social Psychology, 100, 86-100.

Griffin, B., \& Hesketh, B. (2003). Adaptable Behaviours for Successful Work and Career Adjustment. Australian Journal of Pschology, 55(2), 65-73.

Gurcharan, G., \& Shar. (2016). Graduates â€ $€^{\mathrm{TM}}$ Employability Skills. Unitar E-Journal, (March).

Hensel, B. K., Leshner, G., \& Logan, R. A. (n.d.). Consumer Health Informatics Research resource (CHIRr). Retrieved from https://chirr.nlm.nih.gov/index.php

Judge, T. a., Thoresen, C. J., Pucik, V., \& Welbourne, T. M. (1999). Managerial coping with organizational change: A dispositional perspective. Journal of Applied Psychology, 84(1), 107122. https://doi.org/10.1037/0021-9010.84.1.107

Judge, T. A., Thoresen, C. J., Pucik, V., \& Welbourne, T. M. (1999). Managerial Coping With Organizational Change: A Dispositional Perspective Studies of individual behavior in relation to organizational change typically have. Journal of Applied Psychology, 84(1), 107-122.

Latour, M. S., Zahra, S. a, Shaker, a. Z., \& Zahra, S. a. (1989). Fear appeals as advertising strategy: should they be used? Journal of Consumer Marketing, 6(2), 61-70. https://doi.org/10.1108/EUM0000000002548

McMath, B. F., \& Prentice-Dunn, S. (2005). Protection motivation theory and skin cancer risk: The role of individual differences in responses to persuasive appeals. Journal of Applied Social Psychology, 35(3), 621-643. https://doi.org/10.1111/j.1559-1816.2005.tb02138.x

Meijnders, A. L., Midden, C. J. H., \& Wilke, H. a. M. (2001). Communications About Environmental Risks and Risk-Reducing Behavior: The Impact of Fear on Information Processing1. Journal of Applied Social Psychology, 31, 754-777. https://doi.org/10.1111/j.1559-1816.2001.tb01412.x

Meljnders2, A. L., Cees, A., Midden, J. H., \& Wilke, H. A. M. (2001). Communications About Environmental Risks and Risk-Reducing Behavior: The Impact of Fear on Information Processing'.

Milne ${ }^{\sim}$, S., \& Lnrted, S. (2000). Prediction and Intervention in Health-Related Behavior: A Meta- 
Analytic Review of Protection Motivation Theory. Journal ofApplied Social Psychology, 30(1), 106-143. https://doi.org/10.1111/j.1559-1816.2000.tb02308.x

Murphy, M. (2015). Why New Hires Fail (Emotional Intelligence Vs. Skills).

Niessen, C., Swarowsky, C., \& Leiz, M. (2010). Age and adaptation to changes in the workplace. Journal of Managerial Psychology (Vol. 25). https://doi.org/10.1108/02683941011035287

Plotnikoff, R. C., \& Trinh, L. (2010). Protection Motivation Theory: Is This a Worthwhile Theory for Physical Activity Promotion? Exercise \& Sport Sciences Reviews, 38(2), 91-98. https://doi.org/10.1097/JES.0b013e3181d49612

Sekaran, U., \& Bougie, R. (n.d.). RESEARCH METHOS FOR BUSINESS. (wiley, Ed.) (sixth). 2013.

Shujaat, S., Cheema, F., \& Manzoor, A. (2014). Importance of Motivational Factors among Fresh Graduate Employees. IBT Journal of Business Studies (Formerly Journal of Management \& Social Sciences), 10(1), 102-113.

Sim, O. M. (2016). Making Jobless Grads Employable. The Star.

Uitto, Ju. I. (1998). The Geography of Disaster Vulnerability in Megacities.

Welbourne, T. M. (1995). Fear: The Misunderstood Component of Organizational Transformation. Human Resource Planning, 18(1), 30-37.

Wu, C., Tian, A. W., Luksyte, A., \& Spitzmueller, C. (2016). On the Association between Perceived Overqualification and Adaptive Behavior. Personnel Review. https://doi.org/10.1108/PR-052015-0134 